\title{
The effect of Broussonetia papyrifera invasion on the regeneration of selected native timber species in a tropical moist forest in Uganda
}

Davis Mark Ssemanda ( $\square$ davis.ssemanda1@gmail.com )

Makerere University https://orcid.org/0000-0003-2959-0684

Enock Ssekuubwa

Makerere University

\section{Research Article}

Keywords: Abundance, Africa, basal area, invasive alien species, population structure, species composition

Posted Date: August 26th, 2021

DOI: https://doi.org/10.21203/rs.3.rs-831520/v1

License: (c) (i) This work is licensed under a Creative Commons Attribution 4.0 International License. Read Full License 


\section{Abstract}

Broussonetia papyrifera has been identified as one of the top invasive species in some African tropical forests with potentially devastating impacts on the conservation and timber production potential of the forests. This study determined the effect of $B$. papyrifera on the regeneration of selected native timber species in Mabira Forest Reserve, Uganda. The abundance, basal area and population structure of the timber species were compared between areas invaded and uninvaded by B. papyrifera. Employing a complete randomized block design, a total of forty plots (30 x $30 \mathrm{~m}$ each), and equally distributed between invaded and uninvaded areas with similar habitat conditions were surveyed. Counts of seedlings were recorded and diameter of saplings and trees measured. Generalized linear models were used to analyze the abundance, tree basal area and size class distributions of the selected species. The study revealed that the effects of B. papyrifera invasion vary depending on the growth stage and species studied. Overall, $B$. papyrifera invasion significantly reduced tree abundance and basal area, and suppressed the regeneration of some but not all the selected species. Our results demonstrate that if the spread of B. papyrifera is not abated, it will lower the conservation and timber production potential of tropical forests. Therefore, we call for interventions to control the spread of $B$. papyrifera to the uninvaded parts of the forests and halt its multiplication in invaded areas so as to enhance the regeneration and growth of timber species.

\section{Introduction}

Tropical forests are biologically diverse and dynamic, and possess a high order of organization in terms of their microclimates, physiology, and ecological features which are strongly linked (Gibson et al., 2011). In order to maintain such biological diversity, sufficient natural regeneration is required (Baraloto et al., 2005; Gazda et al., 2019). Forest regeneration is a good indicator for forest biodiversity, health and sustainability since it is directly linked with forest management and is therefore essential for preservation and maintenance of biodiversity (Rahman et al., 2011). The nature of forest regeneration depends on site characteristics such as the composition of seed sources, biotic interactions and microsite conditions which affect seed germination and determine the transition from juveniles to mature individuals within a population structure (Wu et al., 2013). Depending on the management objective, it is important to maintain appropriate conditions for forest regeneration as it is essential for the maintenance of biodiversity (Hossain et al., 2004).

There has been growing concern over the impact of alien invasive tree species on the regeneration of native tree species in forest ecosystems (Morgan \& Overholt, 2005). Invasive tree species limit the growth of native juveniles by shedding numerous seeds beneath their canopies which increases the density of emerging seedlings (Dyderski \& Jagodziński, 2020), thereby increasing competition for light and soil resources in the regeneration layer of forests (González-Muñoz et al., 2014; Kawaletz et al., 2014). Invasive species secret chemicals that are toxic to native juveniles and reduce native seed germination (Malik \& Husain, 2007). Also, there have been reports about invasive trees competing for pollinators and seed dispersers with native tree species (Brown \& Mitchell, 2001; Flores-Moreno et al., 2013). Due to their ability for strong vegetative growth, abundant seed production, long-lived seeds and ability to establish over large areas (Dyderski \& Jagodziński, 2020), invasive tree species may reach high biomass and densities and become community dominants (Jagodziński et al., 2018; Lockwood et al., 2005). This alters community structure, composition and function which directly influence recruitment dynamics in forest ecosystems (Terwei et al., 2013; Woziwoda et al., 2019).

Broussonetia papyrifera (L.) L'Herit ex Vent. commonly known as paper mulberry is an alien tree species known to be invasive in at least two African countries; Ghana and Uganda (Adigbli et al., 2019). It is native to Japan and Taiwan where it is cultivated for various purposes which include paper making, cloth making from its bark, and soil stabilization and as a shade tree in home gardens. In Uganda, B. papyrifera was introduced to Mabira, a moist semi-deciduous forest as early as 1956 by forest researchers, in the hope that it would be used for pulp production but this was not achieved because the species did not attain the required diameter as had been expected. This species now covers about 40 percent of the tree composition in Mabira forest and it has invaded other forests in Uganda (MWE, 2017). B. papyrifera's adaptability to different habitats, rapid growth rate, strategy of vegetative regeneration, effective dispersal by birds and allelopathy contribute to its invasion success (Malik \& Husain, 2007).

Although there have been documented benefits of $B$. papyrifera such as provision of firewood, charcoal and fodder, these may not surpass the negative ecological effects. Few studies have attempted to assess the ecological effects of B. papyrifera on native tree species (e.g. Adigbli et al., 2019; Combalicer et al., 2019; Kyereh et al., 2014). Consequently, there are still contentions as different scientists have reported inconsistent effects of the species on native vegetation. For instance, while Agyeman et al. (2016) reported a positive effect of $B$. papyrifera on indigenous species regeneration in Ghana, Apetorgbor and Bosu (2011) reported that the species reduces the abundance of native species. Besides, locally, there is still scanty information about the effects of $B$. papyrifera on the recruitment of indigenous species. Consequently, there is a need for more studies to clarify its effect on native vegetation.

Previous studies show that the influence of invasive species depends on the attributes of the native species. For example, in Missouri, several native species known to be shade tolerant including Desmodium glutinosum and Trillium recurvatum were proportionately less influenced by the invasive Lonicera maacki than light demanders (Witt et al., 2018). Furthermore, the success of an invasive species is mediated by being functionally and predominantly different to the co-existing native species (Mathakutha et al., 2019). Invasive plant species are characterized by high resource acquisition but the localized influence on the native species may be driven by differences in life form between native and invasive species, and variation in soil resource availability (Funk et al., 2017). Consequently, the effect of $B$. papyrifera on tree regeneration likely depends on the attributes of the native species in question. 
This study was intended to contribute to current scholarly debates on the effects of B. papyrifera invasion on the regeneration of native tree species, particularly the timber species. It is expected to provide information that can shape management of tropical forests threatened by alien species invasion in order to enhance native tree regeneration. Forest regeneration is measured in terms of tree growth and stocking (Rand' et al., 1991). Hence, this study assessed the effect of B. papyrifera on the species abundance, basal area and population structure of timber species in Mabira forest in central Uganda. We tested the hypothesis that since alien invasive species limit forest regeneration (Chiba De Castro et al., 2019; Dyderski \& Jagodziński, 2020; Yalley et al., 2020), the abundance and basal area of the selected native species would be lower in areas invaded by $B$. papyrifera compared to uninvaded areas.

\section{Materials And Methods Study area}

Mabira Forest Reserve, located $60 \mathrm{~km}$ East of Kampala city in Central Uganda, is one of Uganda's largest surviving natural forests. Mabira covers about 306 square kilometers, lying in the districts of Mukono and Buikwe. It has been protected as a central forest reserve since 1932 . The forest lies between

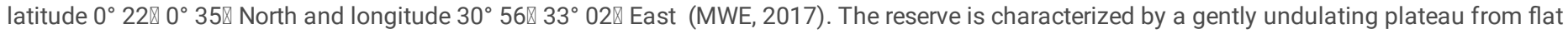
topped hills to wide shallow valleys occupied by swamps. Much of the forest lies between 1,000 to 1,250 meters above sea level with $5 \%$ of the area lying within 1,250 to $1,340 \mathrm{~m}$. The Mabira ecosystem is part of the watershed area for local and international waters of Lakes Kyoga and Victoria, and rivers Nile and Ssezibwa that flow to Lake Kyoga with various tributaries such as Luzibwe, Katogo and Nakasagazi. The soils are ferralitic types which are the final stage of tropical weathering. They are referred to as Buganda catena and are characterized by the topography and not the parent rock, which produces four catenas namely shallow lithosols, red latosols, grey sandy soils and grey clay soils. Red latosols cover much of the Mabira Forest Reserve and surrounding areas.

The forest has an equatorial type of climate characterized by a bimodal pattern of rainfall with two rainy seasons, the first occurring in March, April and May and the second occurring in September, October and November (Nsubuga et al., 2014). The mean annual rainfall is 1,300 mm generally well distributed throughout the year. Temperatures range from an average $26^{\circ} \mathrm{C}$ during day to $16^{\circ} \mathrm{C}$ in the night. The forest supports 229 tree species, 315 bird species, 218 butterfly species, 97 moth species and 23 small mammal species (Davenport et al., 1996). The vegetation of Mabira was classified as medium altitude semi-deciduous, but the forest has largely been influenced by human activities including logging, cultivation and grazing for a long time that it is regarded as a secondary forest. The forest is now largely characterized by vegetation types representing sub climax or human altered plant communities (NFA, 2010). Three vegetation subtypes have been recorded namely the young or colonizing forest dominated by Celtis, Albizia, Antiaris and Funtumia species, the mature mixed forest which constitutes the largest area, 52\% of the area of Mabira, and the Celtis-dominated forest type. Many of the tree species have been noted to grow to timber size (MWE, 2017). Mabira is divided into the production zone, the strict nature reserve and buffer zone which are conservation zones. B. papyrifera is found mostly in the production zone as seedlings and saplings dominating forest gaps created by natural tree falls or tree harvesting (Fig. 1).

\section{Sampling design}

Following a reconnaissance survey, four blocks were demarcated in the production zone of the forest reserve to include areas invaded and uninvaded by B. papyrifera. The distance from one block to the next was about $500 \mathrm{~m}$ in order to capture a wide range of site conditions. Within each block two areas were selected, one invaded and the other un-invaded by B. papyrifera. A uniform distance of about $100 \mathrm{~m}$ was maintained between the invaded and uninvaded areas in all the blocks. The invaded and uninvaded areas were in close proximity in order to assume similar site conditions, including edaphic, climatic and anthropogenic factors. Within each block, one $360 \mathrm{~m}$-long transect was established in the invaded area, and one in the uninvaded area. Along each transect five $30 \times 30$ m plots were established in alternating fashion, to make a total of 40 plots across the four blocks. The first plot was 10 $\mathrm{m}$ from the block edge in consideration of edge effect. A distance of $50 \mathrm{~m}$ was left between the subsequent plots as shown in Fig. 2 . In every $30 \times 30 \mathrm{~m}$ plot, smaller plots of $10 \times 10 \mathrm{~m}$ and $2 \times 2 \mathrm{~m}$ were nested. All the plots were oriented in the North-South direction using a compass.

\section{Study species}

B. papyrifera was studied alongside seven native tree species including Celtis mildbraedii, Chrysophyllum albidum, Funtumia elastica, Holoptelea grandis, Khaya anthotheca, Maesopsis eminii and Markhamia lutea. These are some of the most abundant native tree species in Mabira forest and are also among the most marketable timber species within East Africa (Weldemariam et al., 2017). The species were also accordingly selected basing on shade tolerance and light demand. In this regard, $C$. mildbraedii and $C$. albidum are shade tolerant species, F. elastica and $K$. anthotheca are non-pioneer light demanders, while M. Iutea, H. grandis and M. eminii are pioneer species (Gliniars, 2011). The seedlings of $K$. anthotheca, $H$. grandis and M. eminii are also known to be shade tolerant. H. grandis, F. elastica, K. anthotheca and M. lutea are wind dispersed while C. mildbraedii, C. albidum, M. eminii and B. papyrifera are dispersed by mammals and birds (Babweteera \& Ssekuubwa, 2017; Muller-Landau \& Hardesty, 2009).

\section{Data collection}


The number of trees, saplings, and seedlings was counted for each of the seven native species. The $30 \times 30 \mathrm{~m}$ plots were assessed for trees (diameter at breast height, $\mathrm{dbh} \geq 10 \mathrm{~cm}$ ), $10 \times 10 \mathrm{~m}$ for saplings $(2 \leq \mathrm{dbh}<10 \mathrm{~cm}$ ) and $2 \times 2 \mathrm{~m}$ for seedlings (diameter $<2 \mathrm{~cm}$ and with well-formed leaves) (Bahati, 2005). Diameter at breast height was measured for all trees and saplings using a caliper and a diameter tape for very large trees. Using a Global Positioning System device, coordinates and altitude were collected from the center of each plot. Additional ecological observations of possible relevance such as number of tree falls, number of felled trees and cut poles, presence of trails, fire signs and charcoal pits were also recorded following Sassen and Sheil (2013).

\section{Data analysis}

We calculated total species abundance per plot of seedlings, saplings and trees from the sum of the abundance of selected timber species within a plot, and computed basal area $\left(\mathrm{m}^{2} / \mathrm{ha}\right)$ per plot following Torres \& Lovett (2013). To compare abundance and basal area of the selected timber species between areas invaded and uninvaded by $B$. papyrifera, we fitted generalized linear models using $/ m$ function in $I m e 4$ package in $\mathrm{R}$ version 3.1 .1 (R Core Team, 2020). Model adequacy was checked by use of graphical validation techniques recommended by Zuur et al. (2013), including residuals versus fitted values to verify homogeneity, histograms of the residuals to assess normality, and residuals versus each explanatory variable to check independence.

Population structure of the timber species was assessed using size-class distributions. All individuals encountered in the sample plots were grouped into the following diameter classes: 0-2, 3-9, 10-14, 15-19, 20-24, 25-29, 30-34, 35-39, 40-49, 50-59, 60-79, 80-99, and 100-119. This categorization balances samples across size classes since number of individuals declines with increasing stem diameter (Condit et al., 1998). Stem size-class distributions were generated using the number of individuals and the class midpoints. The number of individuals in each size class was natural log transformed In ( +1$)$ and plotted against the class midpoints on bar graphs (Mwavu \& Witkowski, 2009). The log transformation was used to standardize densities of the different size classes. The addition of 1 to Ni was essential to cater for classes that had zero individuals (Byakagaba et al., 2011; McLaren et al., 2005). We then analyzed the variation of the slopes for each species between the invaded and uninvaded areas with significant variations indicating a difference in the regeneration of a species between the two study areas. Regeneration status of the invaded and uninvaded areas was determined basing on the population size of seedlings, saplings and trees (Gebrehiwot \& Hundera, 2014). One way ANOVA was used to test the significance of the differences in mean species abundance and basal area between the invaded and uninvaded areas. Differences were considered significant at $p<0.05$.

\section{Results}

\subsection{Effect of B. papyrifera on the abundance of selected native timber species}

There was no significant difference in the mean abundances per plot of seedlings and saplings of C. mildbraedii (Fig. 3a), M. lutea (Fig. 3b) and M. eminii (Fig. 3c) between invaded and uninvaded areas (Table 1). However, the mean abundances of trees of C. mildbraedii (Fig. 3a), M. lutea (Fig. 3b) and M. eminii (Fig. 3c), were significantly higher in uninvaded than in the invaded areas (Table 1). The mean abundances of seedlings and trees of $F$. elastica were significantly higher in the uninvaded than in the invaded area (Fig 3d, Table 1). On the other hand, there was no significant difference in the abundance of saplings of $F$. elastica between the invaded and uninvaded areas (Fig $3 \mathrm{~d}$, Table 1). There was no significant variation in mean abundances of seedlings, saplings and trees of $C$. albidum (Fig. 3e), H. grandis (Fig. 3f), and K. anthotheca (Fig. 3g) between the invaded and uninvaded areas (Table 1). Considering all the native timber species, the mean abundance of seedlings was not significantly different between the invaded and uninvaded areas but the mean abundances of saplings and trees were significantly higher in the uninvaded than in the invaded areas (Fig 3h, Table 1).

Table 1 Variation of abundance of selected native timber species in forest areas invaded and uninvaded by B. papyrifera in Mabira Forest Reserve, Central Uganda. The reference category is the invaded area and tests are significant at $p<0.05$ 


\begin{tabular}{|c|c|c|c|c|c|c|c|c|c|c|c|c|}
\hline & Seedlings & & & & Saplings & & & & Trees & & & \\
\hline Forest type & Estimate & $S E$ & $Z$ & $p$ & Estimate & $S E$ & $z$ & $p$ & Estimate & $S E$ & $z$ & $p$ \\
\hline \multicolumn{13}{|l|}{$\begin{array}{l}\text { Celtis } \\
\text { mildbraedii }\end{array}$} \\
\hline Intercept & 3.81 & 0.15 & 25.54 & $<.001$ & 3.09 & 0.21 & 14.50 & $\dot{0}_{0.001}$ & 3.30 & 0.19 & 17.13 & $\begin{array}{l}<.001 \\
0.001\end{array}$ \\
\hline $\begin{array}{l}\text { (Uninvaded- } \\
\text { Invaded) }\end{array}$ & 0.18 & 0.20 & 0.90 & 0.366 & 0.46 & 0.27 & 1.71 & 0.088 & 0.94 & 0.23 & 4.13 & $\begin{array}{l}< \\
0.001\end{array}$ \\
\hline \multicolumn{13}{|l|}{$\begin{array}{l}\text { Markhamia } \\
\text { lutea }\end{array}$} \\
\hline Intercept & 3.50 & 0.17 & 20.09 & $\begin{array}{l}< \\
0.001\end{array}$ & 0.69 & 0.71 & 0.98 & 0.327 & 2.08 & 0.35 & 5.88 & $\begin{array}{l}<.001 \\
0.001\end{array}$ \\
\hline $\begin{array}{l}\text { (Uninvaded- } \\
\text { Invaded) }\end{array}$ & 0.29 & 0.23 & 1.25 & 0.212 & 1.25 & 0.80 & 1.56 & 0.118 & 1.01 & 0.41 & 2.45 & 0.014 \\
\hline \multicolumn{13}{|l|}{$\begin{array}{l}\text { Funtumia } \\
\text { elastica }\end{array}$} \\
\hline Intercept & 5.09 & 0.08 & 65.03 & $<0.001$ & 2.49 & 0.29 & 8.61 & $\dot{0} 001$ & 4.33 & 0.12 & 37.75 & $\begin{array}{l}< \\
0.001\end{array}$ \\
\hline $\begin{array}{l}\text { (Uninvaded- } \\
\text { Invaded) }\end{array}$ & -0.32 & 0.12 & -2.61 & 0.009 & 0.46 & 0.37 & 1.25 & 0.213 & 0.45 & 0.15 & 3.05 & 0.002 \\
\hline \multicolumn{13}{|l|}{$\begin{array}{l}\text { Maesopsis } \\
\text { eminii }\end{array}$} \\
\hline Intercept & -22.30 & 42247.20 & $\dot{0} 001$ & 1.000 & -23.3 & 69653.80 & 0.00 & 1.000 & 1.79 & 0.41 & 4.39 & $\begin{array}{l}< \\
0.001\end{array}$ \\
\hline $\begin{array}{l}\text { (Uninvaded- } \\
\text { Invaded) }\end{array}$ & 22.30 & 42247.20 & 0.00 & 1.000 & 0.00 & 98505.40 & 0.00 & 1.000 & 1.43 & 0.46 & 3.14 & 0.002 \\
\hline \multicolumn{13}{|c|}{$\begin{array}{l}\text { Chrysophyllum } \\
\text { albidum }\end{array}$} \\
\hline Intercept & 1.39 & 0.50 & 2.77 & 0.006 & $<0.001$ & 1.00 & 0.00 & 1.000 & 1.10 & 0.58 & 1.90 & 0.057 \\
\hline $\begin{array}{l}\text { (Uninvaded- } \\
\text { Invaded) }\end{array}$ & -0.69 & 0.87 & -0.80 & 0.423 & $<0.001$ & 1.23 & 0.57 & 0.571 & 1.20 & 0.66 & 1.83 & 0.067 \\
\hline \multicolumn{13}{|l|}{$\begin{array}{l}\text { Holoptelea } \\
\text { grandis }\end{array}$} \\
\hline Intercept & 1.10 & 0.58 & 1.90 & 0.057 & -22.30 & 42247.20 & -0.00 & 1.000 & $<0.001$ & 1.00 & 0.00 & 1.000 \\
\hline $\begin{array}{l}\text { (Uninvaded- } \\
\text { Invaded) }\end{array}$ & -0.41 & 0.91 & -0.44 & 0.657 & 22.30 & 42247.20 & 0.00 & 1.000 & 1.79 & 1.08 & 1.66 & 0.097 \\
\hline \multicolumn{13}{|l|}{$\begin{array}{l}\text { Khaya } \\
\text { anthotheca }\end{array}$} \\
\hline Intercept & 1.39 & 0.50 & 2.77 & 0.006 & $<0.001$ & 1.00 & 0.00 & 1.000 & 1.39 & 0.50 & 2.77 & 0.006 \\
\hline $\begin{array}{l}\text { (Uninvaded- } \\
\text { Invaded) }\end{array}$ & -1.39 & 1.12 & -1.24 & 0.215 & -22.30 & 42250 & -0.001 & 1.000 & -23.689 & 42247.166 & -0.001 & 1.000 \\
\hline \multicolumn{13}{|l|}{$\begin{array}{l}\text { All native } \\
\text { species }\end{array}$} \\
\hline Intercept & 5.529 & 0.063 & 87.78 & $\begin{array}{l}< \\
0.001\end{array}$ & 3.638 & 0.162 & 22.424 & $<.001$ & 4.828 & 0.089 & 53.982 & $\begin{array}{l}<.001 \\
0.001\end{array}$ \\
\hline $\begin{array}{l}\text { (Uninvaded- } \\
\text { Invaded) }\end{array}$ & -0.122 & 0.092 & -1.33 & 0.184 & 0.521 & 0.205 & 2.545 & 0.011 & 0.697 & 0.109 & 6.368 & $\begin{array}{l}< \\
0.001\end{array}$ \\
\hline
\end{tabular}

\subsection{Effect of B. papyrifera on tree basal area of selected native timber species}

The mean tree basal areas of F. elastica (Fig. 4a) and M. eminii (Fig. 4b) were significantly higher in the uninvaded than in invaded area (Table 2). There was no significant difference in mean tree basal areas of C. mildbraedii (Fig. 4c), M. lutea (Fig. 4d), C. albidum (Fig. 4e), H. grandis (Fig. 4f) and K. 
anthotheca (Fig. $4 \mathrm{~g}$ ) between the invaded and uninvaded areas (Table 2). Generally for all timber species, the mean tree basal area was significantly higher in the uninvaded than in the invaded areas. (Fig. 4h, Table 2).

Table 2 Variation of basal area $\left(\mathrm{m}^{2} / \mathrm{ha}\right)$ of timber species in forest areas invaded and uninvaded by B. papyrifera in Mabira Forest Reserve, Central Uganda. The reference category is the invaded area and tests are significant at $p<0.05$

\begin{tabular}{|c|c|c|c|c|}
\hline Forest type & Estimate & SE & $T$ & $P$ \\
\hline \multicolumn{5}{|l|}{ Celtis mildbraedii } \\
\hline Intercept & 0.872 & 0.696 & 1.252 & 0.218 \\
\hline Forest(Uninvaded-Invaded) & 1.407 & 0.985 & 1.428 & 0.161 \\
\hline \multicolumn{5}{|l|}{ Markhamia lutea } \\
\hline Intercept & 0.591 & 0.406 & 1.457 & 0.153 \\
\hline Forest (Uninvaded-Invaded) & -0.259 & 0.406 & -0.452 & 0.654 \\
\hline \multicolumn{5}{|l|}{ Funtumia elastica } \\
\hline Intercept & 0.724 & 0.320 & 2.263 & 0.029 \\
\hline Forest (Uninvaded-Invaded) & 0.939 & 0.452 & 2.075 & 0.045 \\
\hline \multicolumn{5}{|l|}{ Maesopsis eminii } \\
\hline Intercept & 0.156 & 0.306 & 0.512 & 0.612 \\
\hline Forest (Uninvaded-Invaded) & 0.955 & 0.432 & 2.211 & 0.033 \\
\hline \multicolumn{5}{|l|}{ Chrysophyllum albidum } \\
\hline Intercept & 0.033 & 0.119 & 0.280 & 0.781 \\
\hline Forest (Uninvaded-Invaded) & 0.219 & 0.168 & 1.304 & 0.200 \\
\hline \multicolumn{5}{|l|}{ Holoptelea grandis } \\
\hline Intercept & 0.043 & 0.102 & 0.425 & 0.673 \\
\hline Forest (Uninvaded-Invaded) & 0.128 & 0.144 & 0.886 & 0.381 \\
\hline \multicolumn{5}{|l|}{ Khaya anthotheca } \\
\hline Intercept & 0.209 & 0.144 & 1.456 & 0.154 \\
\hline Forest (Uninvaded-Invaded) & -0.209 & 0.203 & -1.030 & 0.310 \\
\hline \multicolumn{5}{|l|}{ All native species } \\
\hline Intercept & 2.629 & 0.895 & 2.938 & 0.006 \\
\hline Forest (Uninvaded-Invaded) & 3.179 & 1.266 & 2.511 & 0.016 \\
\hline
\end{tabular}

\subsection{Effect of B. papyrifera on the population structure of selected native timber species}

We found a variation in the population structure of the timber species in the invaded and uninvaded areas. C. mildbraedii (Fig. 5a) and F. elastica (Fig. $5 \mathrm{c}$ ) showed a classic inverse $\mathrm{J}$ curve distribution in both the invaded and uninvaded areas indicating sufficient regeneration. $M$ lutea (Fig. $5 \mathrm{~b}$ ) showed the classic inverse $\mathrm{J}$ curve distribution in the uninvaded forest. The same species portrayed distribution that tended towards the classic inverse $\mathrm{J}$ curve in the invaded forest, but lacking individuals in the $\mathrm{dbh}>12 \mathrm{~cm}$ class. M. eminii (Fig. $5 \mathrm{~d}$ ) and C. albidum (Fig. 5 e) showed uneven distribution in the uninvaded forest. $M$ eminii, however, had individuals of only two size classes (22 and $27 \mathrm{~cm} \mathrm{dbh)} \mathrm{represented} \mathrm{in} \mathrm{the} \mathrm{invaded} \mathrm{forest,} \mathrm{while} C$. albidum did not have any individuals of $\mathrm{dbh}>17 \mathrm{~cm}$ in the invaded forest. $H$. grandis lacked representation across most of the size classes in both forest areas but with more classes found in the uninvaded (4) than in the invaded (2).

When considered as a group, the timber species had stem size class distribution curves that conform to the classic 'inverse $\mathrm{J}$ ' curve in both forest areas although some size classes were completely not represented in the invaded forest while all classes were represented in the uninvaded areas (Fig. $5 \mathrm{~g}$ ). The regeneration of individuals was significantly higher in the uninvaded than in the invaded areas for M. eminii and $K$. anthotheca (Table 3 ). 
Table 3 Variation of slopes of the size-class distributions of timber species in forest areas invaded and uninvaded by B. papyrifera in Mabira Forest Reserve, Uganda

\begin{tabular}{|c|c|c|c|c|}
\hline Forest type & Estimate & $S E$ & $t$ & $p$ \\
\hline \multicolumn{5}{|l|}{ Celtis mildbraedii } \\
\hline Intercept & 1.341 & 0.343 & 3.908 & $<0.001$ \\
\hline Forest (Uninvaded-Invaded) & 0.489 & 0.485 & 1.007 & 0.324 \\
\hline \multicolumn{5}{|l|}{ Markhamia lutea } \\
\hline Intercept & 0.569 & 0.330 & 1.723 & 0.098 \\
\hline Forest (Uninvaded-Invaded) & 0.301 & 0.467 & 0.645 & 0.525 \\
\hline \multicolumn{5}{|l|}{ Funtumia elastica } \\
\hline Intercept & 1.315 & 0.485 & 2.714 & 0.012 \\
\hline Forest (Uninvaded-Invaded) & 0.448 & 0.685 & 0.654 & 0.519 \\
\hline \multicolumn{5}{|l|}{ Maesopsis eminii } \\
\hline Intercept & 0.208 & 0.184 & 1.131 & 0.269 \\
\hline Forest (Uninvaded-Invaded) & 0.610 & 0.260 & 2.341 & 0.028 \\
\hline \multicolumn{5}{|l|}{ Chrysophyllum albidum } \\
\hline Intercept & 0.315 & 0.158 & 1.993 & 0.058 \\
\hline Forest (Uninvaded-Invaded) & 0.236 & 0.224 & 1.058 & 0.300 \\
\hline \multicolumn{5}{|l|}{ Holoptelea grandis } \\
\hline Intercept & 0.160 & 0.139 & 1.150 & 0.262 \\
\hline Forest (Uninvaded-Invaded) & 0.169 & 0.197 & 0.859 & 0.399 \\
\hline \multicolumn{5}{|l|}{ Khaya anthotheca } \\
\hline Intercept & 0.213 & 0.065 & 3.266 & 0.003 \\
\hline Forest (Uninvaded-Invaded) & -0.213 & 0.092 & -2.309 & 0.030 \\
\hline \multicolumn{5}{|l|}{ All Native species } \\
\hline Intercept & 4.122 & 1.366 & 3.016 & 0.006 \\
\hline Forest (Uninvaded-Invaded) & 2.040 & 1.932 & 1.056 & 0.302 \\
\hline
\end{tabular}

\section{Discussion}

Overall, we found inconsistent effects of B. papyrifera on the abundance, basal area and population structure of the timber species. Our results should be interpreted cautiously because we studied only seven species from a highly diverse ecosystem with over 229 tree species (Davenport et al., 1996). Nonetheless, our results are relevant to tropical forest management as these species are the most commercially harvested in our study region and East Africa (Weldemariam et al., 2017).

\subsection{Effect of B. papyrifera invasion on abundance of selected native timber species}

Our results showed that the effect of $B$. papyrifera on species abundance is not straight forward but depends on the growth stage (i.e. seedlings, saplings and trees) and species studied. First, while the abundance of seedlings and saplings of $C$. mildbraedii, M. Iutea and $M$. eminii did not vary between invaded and uninvaded areas, the abundance of trees of these species was lower in the invaded areas. Second, $C$. albidum, $H$. grandis and $K$. anthotheca did not respond to $B$. papyrifera invasion in contrast to $C$. mildbreadii, M. lutea, $M$. eminii and $F$. elastica for which the tree abundance was lower in invaded area. We suggest that in order to achieve a holistic assessment of the effect of invasive species on forest regeneration in diverse ecosystems like tropical forests, it is critical to inventory the different growth stages and to include more than one species if resources permit. 
Considering a single growth stage and/or species would potentially underestimate the impact of invasion on native species. The lower tree abundance of $C$. mildbreadii, M. lutea, M. eminii and F. elastica and for all species combined in the invaded area is consistent with our hypothesis and may be attributed to invasive characteristics of B. papyrifera such as altering soil properties as reported by Anning et al. (2018), allelopathy and high evapotranspiration ability making site conditions unfavorable (Yalley et al., 2020) and causing stunting of juveniles of native species. This affects forest regeneration by potentially hindering the transition from juveniles (seedlings and saplings) to the older (tree) stages which has negative consequences for forest sustainability (Zambrano et al., 2014). The generally low abundance of $K$. anthotheca, $H$. grandis, and $C$. albidum in both forest types is congruent with other studies carried out in Mabira forest (Weldemariam et al., 2017). The fact that the juvenile abundance of certain native species is not affected by invasion is not clearly understood but could partly be linked to species functional traits such as the seedlings of the unaffected species being shade tolerant and are therefore not affected by canopy closure by B. papyrifera (V. K. Agyeman et al., 2010; Kiama \& Kiyiapi, 2001). It has also been suggested that $B$. papyrifera may have facilitative effects by fostering the establishment of seedlings and saplings of some native species ( $V$. Agyeman et al., 2016; Yalley et al., 2020) but this remains a subject for further research.

\subsection{Effect of $B$. papyrifera invasion on basal area of timber species}

Consistent with our observations on species abundance, the effect of $B$. papyrifera invasion on basal area of native species varied by study species reiterating the importance of including more than a single native species in invasion studies of diverse ecosystems like tropical forests. We found that the mean basal area of $M$. eminii and $F$. elastica and for all species combined was lower in the invaded than uninvaded areas which is likely because of the overwhelming dominance of $B$. papyrifera in the invaded forest. Our results are consistent with our hypothesis and the findings by Weldemariam et al. (2017) that B. papyrifera dominates the invaded areas and shows that the invasive species have a competitive advantage over the native species. Since basal area is a measure of a species' competitive ability (Maleki et al., 2015; Wright et al., 2018), then B. papyrifera should have a higher basal area in the invaded area than the native species studied for it to be more competitive. Indeed, the basal area (Mean $\left.\pm \mathrm{SE} \mathrm{m}^{2} / \mathrm{ha}\right)$ of $B$. papyrifera (12.820 \pm $1.570)$ was substantially higher than that of $M$. lutea $(0.591 \pm 0.546), K$. anthotheca $(0.209 \pm 0.203)$, C. mildbraedii (0.872 \pm 0.379$)$, M. eminii (0.156 \pm $0.093)$, F. elastica $(0.724 \pm 0.202), H$. grandis $(0.043 \pm 0.043)$, and $C$. albidum $(0.033 \pm 0.025)$ and for all species combined $(2.629 \pm 0.770)$ in the invaded area. The higher competitive ability of $B$. papyrifera could be due to the fact that it fruits twice a year and achieves reproductive maturity at a relatively small size, as well as its ability to regenerate from seeds, root suckers, and stumps (Kyereh et al., 2014). Although there is no significant difference between the basal area for $C$. mildbraedii, $M$. Iutea, $C$. albidum, $H$. grandis and $K$. anthotheca between invaded and uninvaded areas, there is a possibility that this could change in the coming years due to the rapid multiplication of B. papyrifera as reported by Adigbli et al. (2019) in a study from a Ghanaian tropical forest.

\subsection{Effect of B. papyrifera invasion on population structure of timber species}

M. eminii, C. albidum, $H$. grandis and $K$. anthotheca had size class distribution slopes that deviated from the classic 'inverse J' curve in the invaded area probably due to the under representation and complete absence of individuals in some size classes. The population structure of these species in the uninvaded areas were significantly different from that in the invaded. However, the invasion by $B$. papyrifera explains only a very small percentage of the populations $\left(\mathrm{R}^{2}<0.03\right)$ for $H$. grandis and $K$. anthotheca and therefore cannot elucidate the differences entirely. Since the invaded area was only slightly more disturbed than the uninvaded area $\left(\chi^{2}=3.82, d f=1, p<0.051\right.$; Table S1, Fig. S1), we think that besides $B$. papyrifera invasion, environmental factors could influence the populations of $H$. grandis and $K$. anthotheca (Gwali et al., 2015; Kimaro \& Lulandala, 2013). The absence of individuals in certain size classes in the invaded forest, especially the medium classes $15-59 \mathrm{~cm}$ DBH for almost all species besides $C$. mildbraedii could be due to the influence of $B$. papyrifera on the light availability, soil fertility and allelopathic effect limiting recruitment of the native species. This is consistent with the findings of Kyereh et al. (2014) and Apetorgbor and Bosu (2011) who reported that B. papyrifera invasion has the capacity to reduce the composition of some native species by suppressing their regeneration.

\section{Conclusions}

Our study reveals that the effect of $B$. papyrifera invasion on forest regeneration is not straight forward and depends on the growth stage considered and the study species highlighting the importance of including different growth stages and more than one species in invasion studies for diverse ecosystems like tropical forests. Overall, we found that $B$. papyrifera invasion reduced the abundance and basal area of trees of timber species. Also most species were under-represented or completely lacked individuals in some size classes, particularly juveniles, in the invaded forest indicating a sporadic regeneration pattern. We recommend that the timber production potential of the forest can be sustained by reducing the density of $B$. papyrifera in the invaded area in order to foster the transition from juveniles to older growth stages for C. mildbreadii, M. Iutea, M. eminii and F. elastica, in addition to addressing the generally low abundance of $C$. albidum, $K$. anthotheca and $H$. grandis through enrichment planting of these species in invaded and uninvaded areas. These management actions would probably reduce the competitive ability and spread of $B$. papyrifera, enhance the basal area and promote healthy population structures of the timber species. We propose future studies to investigate the performance of the timber species and $B$. papyrifera under the proposed management actions.

Page 8/16 


\section{Declarations \\ Funding}

This research did not receive any specific grant or funding from any funding agency in the public, commercial, or not-for-profit sectors.

\section{Conflicts of interest}

The authors have no conflicting interests to disclose.

\section{Availability of data and materials}

The data for reproducing all results and figures are available in Zenodo.org at http://doi.org/10.5281/zenodo.5212514

\section{Code availability}

No custom code was used for analyses, all functions used in analyzing data were acknowledged and respective R packages were cited.

\section{Authors' contributions}

The authors confirm contribution to the paper as follows: study conception and design: D.M.S. and E.S.; data collection: D.M.S.; analysis and interpretation of results: D.M.S. and E.S.; draft manuscript preparation: D.M.S. and E.S. Both authors reviewed the results and approved the final version of the manuscript.

\section{Ethics approval}

This article does not contain any studies involving human participants performed by any of the authors.

\section{Consent to participate}

Not applicable

\section{Consent for publication}

Not applicable

\section{Acknowledgements}

Our sincere gratitude goes to Deogratius Balidawo and Onesmus Assimwe of Mabira Forest Reserve who assisted in data collection.

\section{References}

Adigbli DM, Anning AK, Adomako JK, Fosu-Mensah BY (2019) Effects of Broussonetia papyrifera invasion and land use on vegetation characteristics in a tropical forest of Ghana. Journal of Forestry Research 30(4):1363-1373. https://doi.org/10.1007/s11676-018-0691-9

Agyeman V, Addo-Danso SD, Kyereh B, Abebrese IK (2016) Vegetation assessment of native tree species in Broussonetia papyrifera-dominated degraded forest landscape in southern Ghana. Appl Veg Sci 19(3):498-507. https://doi.org/10.1111/avsc.12241

Agyeman VK, Kyereh B, Thompson J (2010) Species differences in seedling growth and leaf water response to light quality. In Ghana J. Forestry (Vol. 26) Anning AK, Gyamfi B, Effah AT (2018) Broussonetia papyrifera controls nutrient return to soil to facilitate its invasion in a tropical forest of Ghana. Journal of Plant Ecology 11(6):909-918. https://doi.org/10.1093/jpe/rtx058

Apetorgbor M, Bosu PP (2011) Occurrence and control of paper mulberry (broussonetia papyrifera) in southern Ghana. Ghana Journal of Forestry 27:11-22 
Babweteera F, Ssekuubwa E (2017) Predicting which tropical tree species are vulnerable to forest disturbances. Afr J Ecol 55(4):592-599. https://doi.org/10.1111/aje.12393

Baraloto C, Goldberg DE, Bonal D (2005) Performance trade-offs among tropical tree seedlings in contrasting microhabitats. Ecology. https://doi.org/10.1890/04-1956

Brown BJ, Mitchell RJ (2001) Competition for pollination: Effects of pollen of an invasive plant on seed set of a native congener. Oecologia 129(1):4349. https://doi.org/10.1007/s004420100700

Byakagaba P, Eilu G, Okullo JBL, Tumwebaze SB, Mwavu EN (2011) Population Structure and Regeneration Status of Vitellaria paradoxa (C.F.Gaertn.) Under Different Land Management Regimes in Uganda. Agricultural Journal 6(1):14-22. https://doi.org/10.3923/aj.2011.14.22

Chiba De Castro, WA, Xavier RO, Garrido FHL, Romero JHC, Peres CK, Da Luz RC (2019) Fraying around the edges: Negative effects of the invasive Tradescantia zebrina Hort. ex Bosse (Commelinaceae) on tree regeneration in the Atlantic Forest under different competitive and environmental conditions. Journal of Plant Ecology 12(4):713-721. https://doi.org/10.1093/jpe/rtz009

Combalicer MS, Carayugan MBA, Hernandez JO (2019) Allelopathic property of an invasive tree Broussonetia papyrifera (L.) Iher. ex vent in its introduced range in mount makiling forest reserve, Philippines. Philippine Journal of Science 148(4):609-618

Condit R, Sukumar R, Hubbell SP, Foster RB (1998) Predicting population trends from size distributions: A direct test in a tropical tree community. Am Nat 152(4):495-509. https://doi.org/10.1086/286186

Davenport T, Howard P, Baltzer M, \& Uganda Forest Department. (1996). Mabira Forest Reserve: Biodiversity Report - Uganda. Forest Department - Google Books. https://books.google.co.ug/books/about/Mabira_Forest_Reserve.html?id=aliUPgAACAAJ\&redir_esc=y

Dyderski MK, Jagodziński AM (2020) Impact of Invasive Tree Species on Natural Regeneration Species Composition, Diversity, and Density. Forests 11(4):456. https://doi.org/10.3390/f11040456

Flores-Moreno H, Thomson FJ, Warton DI, Moles AT (2013) Are Introduced Species Better Dispersers Than Native Species? A Global Comparative Study of Seed Dispersal Distance. PLoS ONE 8(6):e68541. https://doi.org/10.1371/journal.pone.0068541

Funk JL, Nguyen MA, Standish RJ, Stock WD, Valladares F (2017) Global resource acquisition patterns of invasive and native plant species do not hold at the regional scale in Mediterranean type ecosystems. Biol Invasions 19(4):1143-1151. https://doi.org/10.1007/s10530-016-1297-9

Gazda A, Kościelniak P, Hardy M, Muter E, Kędra K, Bodziarczyk J, Frączek M, Chwistek K, Różański W, Szwagrzyk J (2019) Upward expansion of distribution ranges of tree species: Contrasting results from two national parks in Western Carpathians. Sci Total Environ 653:920-929.

https://doi.org/10.1016/j.scitotenv.2018.10.360

Gebrehiwot K, Hundera K (2014) Species composition, Plant Community structure and Natural regeneration status of Belete Moist Evergreen Montane Forest, Oromia Regional state, Southwestern Ethiopia. Momona Ethiopian Journal of Science 6(1):97-101. https://doi.org/10.4314/mejs.v6i1.102417

Gibson L, Lee TM, Koh LP, Brook BW, Gardner TA, Barlow J, Peres CA, Bradshaw CJA, Laurance WF, Lovejoy TE, Sodhi NS (2011) Primary forests are irreplaceable for sustaining tropical biodiversity. Nature 2011 478:7369(7369):378-381. https://doi.org/10.1038/nature10425 478 ) .

Gliniars R (2011) Tree Growth and Tree Regeneration in Two East African Rain Forests as related to the Abiotic Environment after Human Disturbance. Dissertation, University of Hohenheim, Germany, 210,1-198. opus.ub.uni-hohenheim.de

González-Muñoz N, Castro-Díez P, Godoy O (2014) Lack of superiority of invasive over co-occurring native riparian tree seedling species. Biol Invasions 16(2):269-281. https://doi.org/10.1007/s10530-013-0516-x

Gwali S, Agaba H, Balitta P, Hafashimana D, Nkandu J, Kuria A, Pinard F, Sinclair F (2015) Tree species diversity and abundance in coffee farms adjacent to areas of different disturbance histories in Mabira forest system, central Uganda. International Journal of Biodiversity Science Ecosystem Services Management 11(4):309-317. https://doi.org/10.1080/21513732.2015.1050607

Hossain MK, Rahman ML, Hoque ATMR, Alam MK (2004) Comparative regeneration status in a natural forest and enrichment plantations of Chittagong (south) forest division, Bangladesh. Journal of Forestry Research 15(4):255-260. https://doi.org/10.1007/bf02844948

Jagodziński AM, Dyderski MK, Horodecki P, Rawlik K (2018) Limited dispersal prevents Quercus rubra invasion in a 14-species common garden experiment. Divers Distrib 24(3):403-414. https://doi.org/10.1111/ddi.12691

Kawaletz H, Mölder I, Annighöfer P, Terwei A, Zerbe S, Ammer C (2014) Back to the roots: How do seedlings of native tree species react to the competition by exotic species? Ann For Sci 71(3):337-347. https://doi.org/10.1007/s13595-013-0347-z

Kiama D, Kiyiapi J (2001) Shade tolerance and regeneration of some tree species of a tropical rain forest in western Kenya. Plant Ecol 156(2):183-191. https://doi.org/10.1023/A:1012602930347

Page 10/16 
Kimaro J, Lulandala L (2013) Human Influences on Tree Diversity and Composition of a Coastal Forest Ecosystem: The Case of Ngumburuni Forest Reserve, Rufiji, Tanzania. International Journal of Forestry Research, 2013, 1-7. https://doi.org/10.1155/2013/305874

Kyereh B, Agyeman VK, Abebrese IK (2014) Ecological Characteristics That Enhance Broussonetia papyrifera 's Invasion in a Semideciduous Forest in Ghana. Journal of Ecosystems, 2014, 1-6. https://doi.org/10.1155/2014/270196

Lockwood JL, Cassey P, Blackburn T (2005) The role of propagule pressure in explaining species invasions. Trends in Ecology Evolution 20(5):223-228. https://doi.org/10.1016/j.tree.2005.02.004

Maleki K, Kiviste A, Korjus H (2015) Analysis of individual tree competition effect on diameter growth of silver birch in Estonia. Forest Systems, 24(2). https://doi.org/10.5424/fs/2015242-05742

Malik RN, Husain SZ (2007) Broussonetia papyrifera (L.) I'hér. ex vent.: An environmental constraint on the Himalayan Foothills vegetation. Pak J Bot 39(4):1045-1053

Mathakutha R, Steyn C, le Roux PC, Blom IJ, Chown SL, Daru BH, Ripley BS, Louw A, Greve M (2019) Invasive species differ in key functional traits from native and non-invasive alien plant species. J Veg Sci 30(5):994-1006. https://doi.org/10.1111/jvs.12772

McLaren KP, McDonald MA, Hall JB, Healey JR (2005) Predicting Species Response to Disturbance from Size Class Distributions of Adults and Saplings in a Jamaican Tropical Dry Forest. Plant Ecol 2005 181:1(1):69-84. https://doi.org/10.1007/S11258-005-3497-8 181 ) .

Morgan EC, Overholt WA (2005) Potential allelopathic effects of Brazilian pepper (Schinus terebinthifolius Raddi, Anacardiaceae) aqueous extract on germination and growth of selected Florida native plants. Journal of the Torrey Botanical Society 132(1):11-15. https://doi.org/10.3159/10955674(2005)132[11:PAEOBP]2.0.C0;2

Muller-Landau HC, Hardesty BD (2009) Seed dispersal of woody plants in tropical forests: concepts, examples and future directions. Biotic Interactions in the Tropics, 267-309. https://doi.org/10.1017/CBO9780511541971.012

Mwavu EN, Witkowski ETF (2009) Population structure and regeneration of multiple-use tree species in a semi-deciduous African tropical rainforest: Implications for primate conservation. For Ecol Manage 258(5):840-849. https://doi.org/10.1016/j.foreco.2009.03.019

MWE (2017) Revised forest management plan for Mabira Central Forest Reserves. Ministry of Water and Environment. Republic of Uganda

Nsubuga FWN, Botai OJ, Olwoch JM, Rautenbach CJ, deW, Bevis Y, Adetunji AO (2014) The nature of rainfall in the main drainage sub-basins of Uganda. Https://Doi.Org/10.1080/02626667.2013.804188, 59(2), 278-299. https://doi.org/10.1080/02626667.2013.804188

R Core Team (2020) R: a language and environment for statistical computing. Version 4.0.2. In: R Foundation for Statistical Computing. R Foundation for Statistical Computing

Rahman MH, Khan MASA, Roy B, Fardusi MJ (2011) Assessment of natural regeneration status and diversity of tree species in the biodiversity conservation areas of Northeastern Bangladesh. Journal of Forestry Research 22(4):551-559. https://doi.org/10.1007/s11676-011-0198-0

Rand' DG, Leckie DG, Cloney EE (1991) Forest regeneration surveys: Design, data collection, and analysis

Sassen M, Sheil D (2013) Human impacts on forest structure and species richness on the edges of a protected mountain forest in Uganda. For Ecol Manage 307:206-218. https://doi.org/10.1016/j.foreco.2013.07.010

Terwei A, Zerbe S, Zeileis A, Annighöfer P, Kawaletz H, Mölder I, Ammer C (2013) Which are the factors controlling tree seedling establishment in North Italian floodplain forests invaded by non-native tree species? For Ecol Manage 304:192-203. https://doi.org/10.1016/j.foreco.2013.05.003

Torres AB, Lovett JC (2013) Using basal area to estimate aboveground carbon stocks in forests: La Primavera Biosphere's Reserve, Mexico. Forestry 86:267-281. https://doi.org/10.1093/forestry/cps084

Weldemariam E, Jakisa E, Ahebwe D (2017) Implication of forest zonation on tree species composition, diversity and structure in Mabira Forest, Uganda. Environment Earth Ecology 1(1):112-122. https://doi.org/10.24051/eee/69224

Witt A, Beale T, van Wilgen BW (2018) An assessment of the distribution and potential ecological impacts of invasive alien plant species in eastern Africa. Transactions of the Royal Society of South Africa 73(3):217-236. https://doi.org/10.1080/0035919X.2018.1529003

Woziwoda B, Dyderski MK, Jagodziński AM (2019) Effects of land use change and Quercus rubra introduction on Vaccinium myrtillus performance in Pinus sylvestris forests. For Ecol Manage 440:1-11. https://doi.org/10.1016/j.foreco.2019.03.010

Wright M, Sherriff RL, Miller AE, Wilson T (2018) Stand basal area and temperature interact to influence growth in white spruce in southwest Alaska. Ecosphere 9(10):e02462. https://doi.org/10.1002/ECS2.2462

Page $11 / 16$ 
Wu J, Lin W, Peng X, Liu W (2013) A Review of Forest Resources and Forest Biodiversity Evaluation System in China. International Journal of Forestry Research, 2013, 1-7. https://doi.org/10.1155/2013/396345

Yalley MK, Adusu D, Bunyamin AR, Okyere I, Asare A (2020) Natural Regeneration of Indigenous Tree Species in Broussonetia papyrifera Invaded Sites in Pra-Anum Forest Reserve. International Journal of Forestry Research, 2020, 1-9. https://doi.org/10.1155/2020/6347962

Zambrano J, Science C, Lucia S (2014) Forest Fragmentation Alters the Population Dynamics of a Late-successional Tropical Tree. 46(5), 556-564

Zuur AF, Hilbe JM, leno EN (2013) A beginner's guide to GLM and GLMM with R. A frequentist and Bayesian perspective for ecologists. Highland Statistics Ltd

\section{Figures}
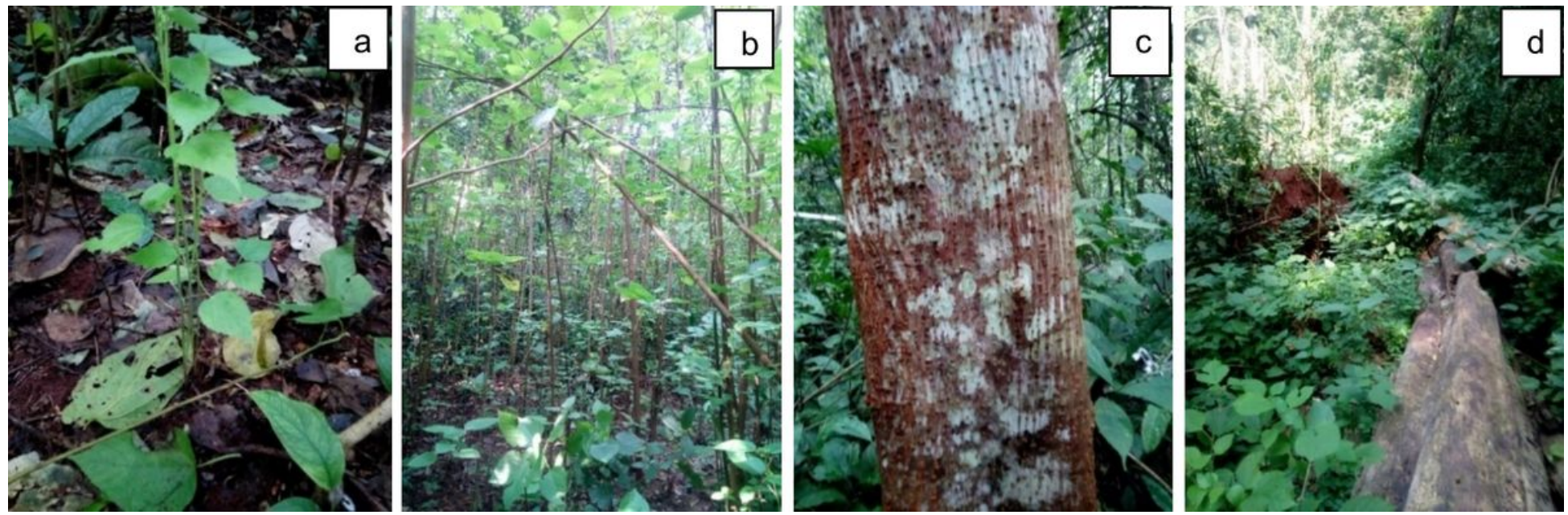

\section{Figure 1}

(a) Broussonetia papyrifera seedling (b) saplings and (c) tree stem, and a forest gap, essential for regeneration (d) 


\section{A map showing the location of sample plots for data collection}

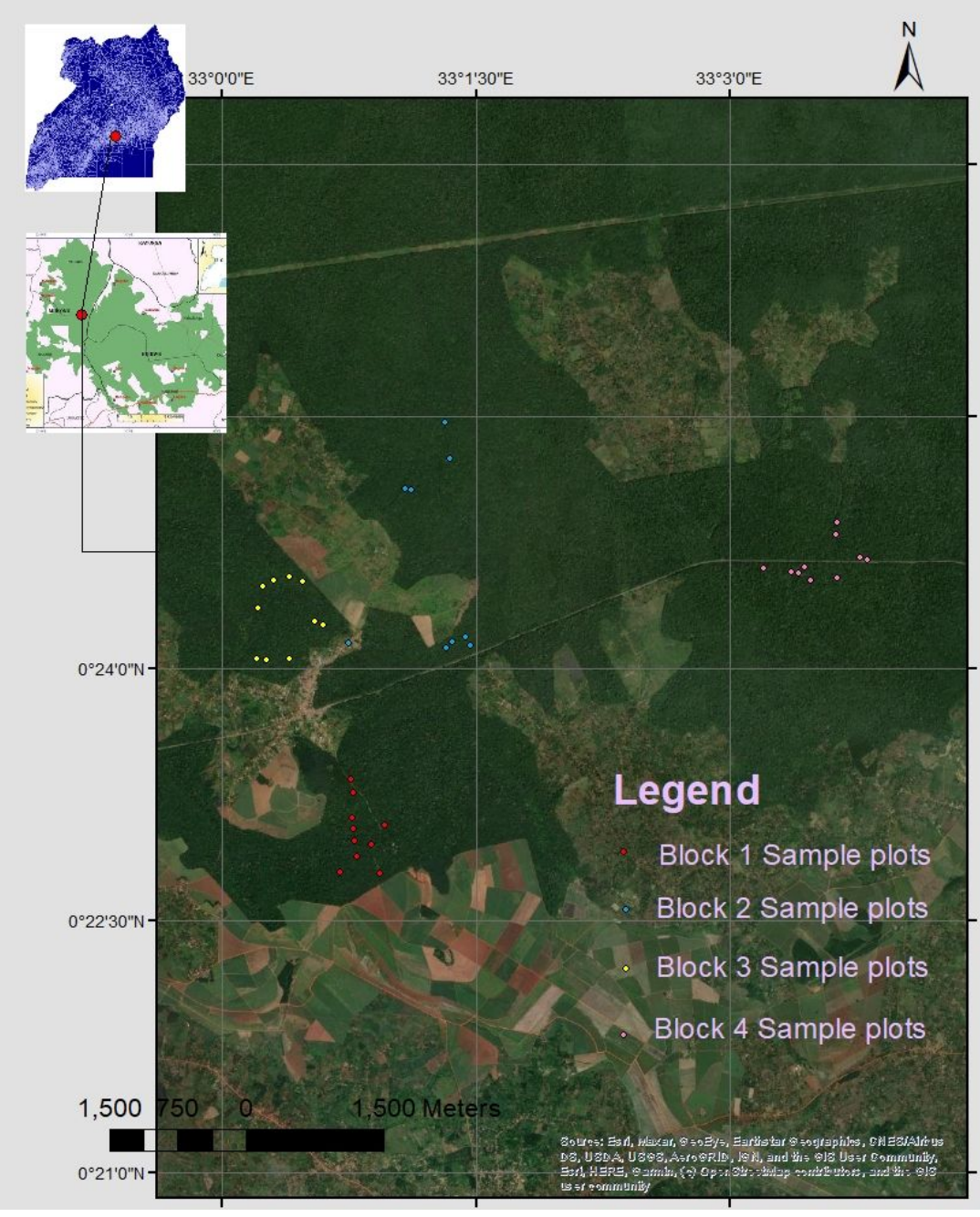

Figure 2

Location of sample plots for data collection in Mabira Forest Reserve, Uganda 

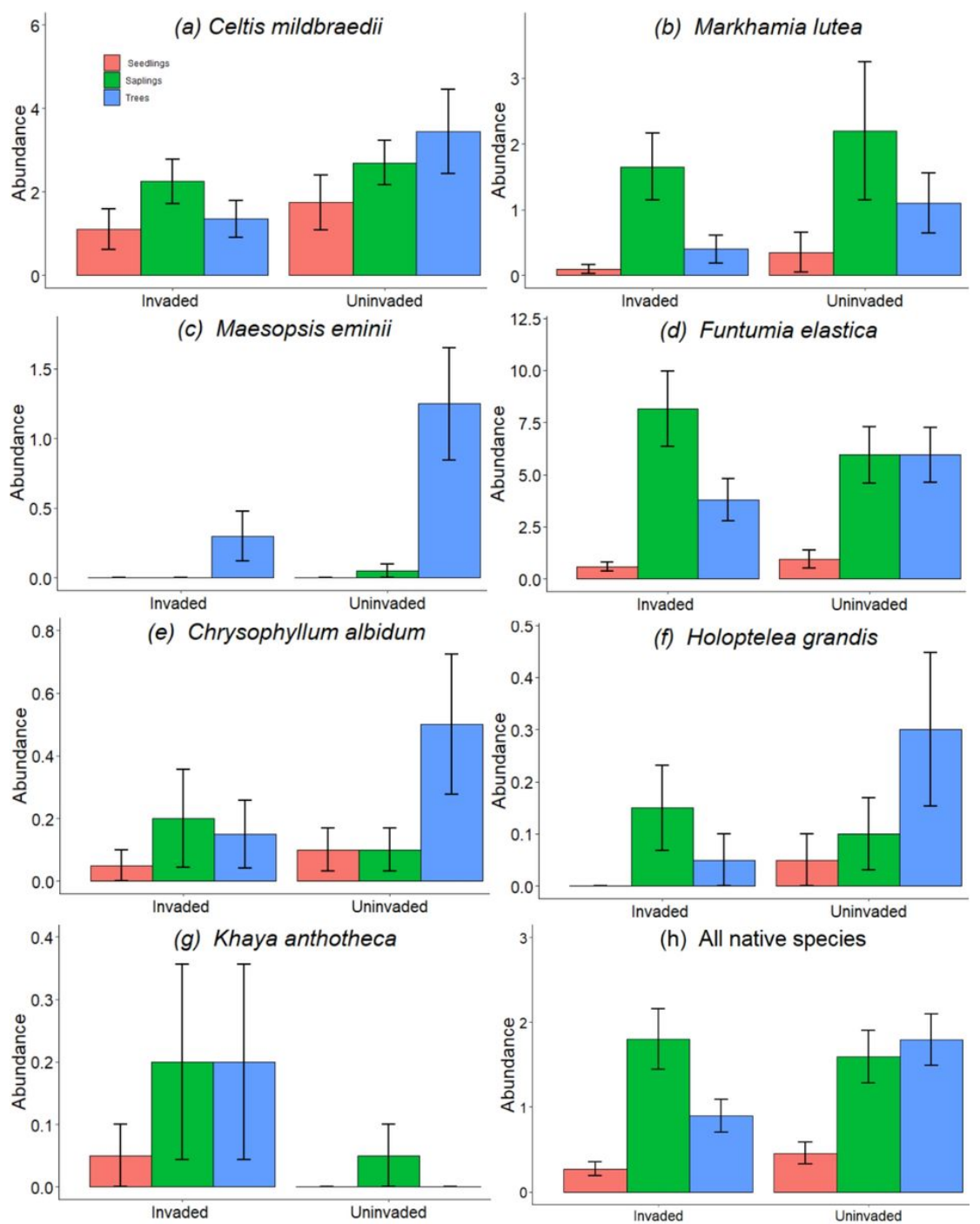

Figure 3

Variation of abundance of native timber species in forest areas invaded and uninvaded by B. papyrifera in Mabira Forest Reserve, Central Uganda 

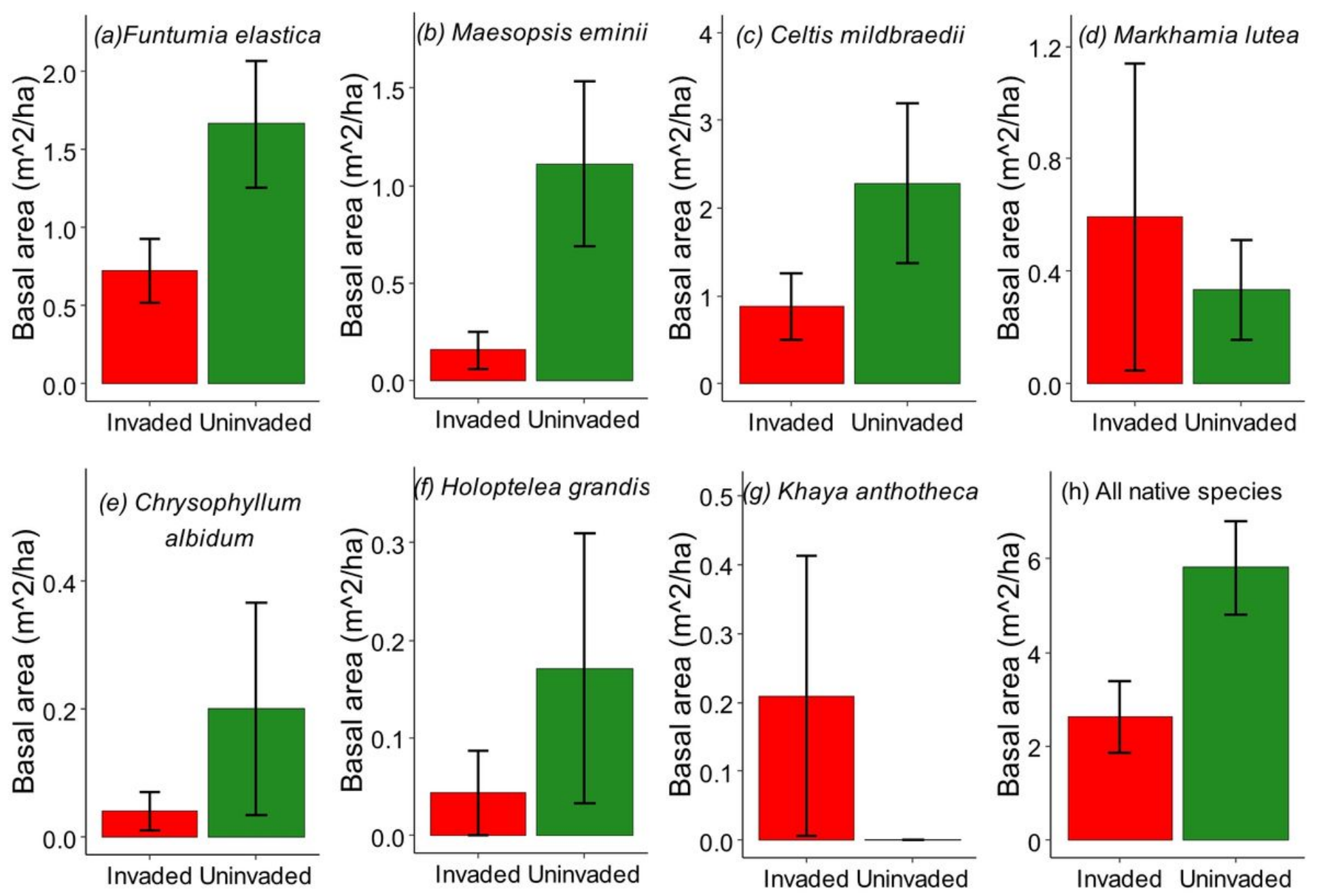

Figure 4

Variation of basal area (m2/ha) of timber species in forest areas invaded and uninvaded by B. papyrifera in Mabira Forest Reserve, Central Uganda 

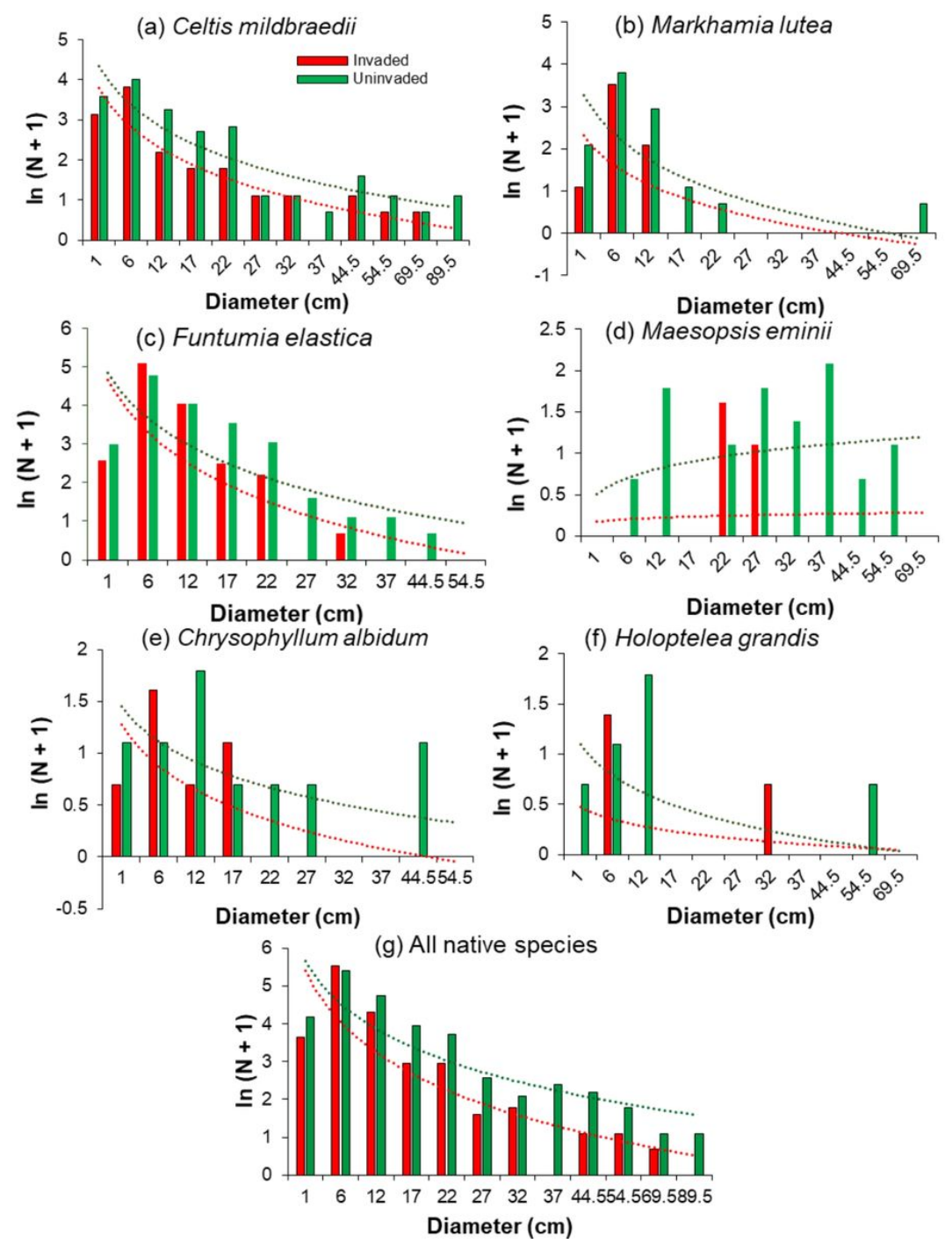

Figure 5

Stem size-class distributions (SCD) exhibited by timber species in forest areas invaded and uninvaded by B. papyrifera in Mabira Forest Reserve, Uganda, arranged according to SCD slope values. Midpoints of the classes are plotted

\section{Supplementary Files}

This is a list of supplementary files associated with this preprint. Click to download.

- SupportinginformationBroussonetiapapyriferainvasion.docx 